\title{
Transparent Theological Dialogue-“Moseka Phofu Ya Gaabo Ga a Tshabe Go Swa Lentswe" (A Setswana Proverb)
}

\author{
Kelebogile Thomas Resane ${ }^{(i)}$
}

Department of Historical \& Constructive Theology, University of the Free State, Bloemfontein 9301, Free State, South Africa; ResaneKT@ufs.ac.za

Received: 29 November 2017; Accepted: 9 February 2018; Published: 9 February 2018

\begin{abstract}
This paper looks into the definition of Setswana ${ }^{1}$ proverb: Moseka phofu ya gaabo ga a tshabe go swa lentswe (One must fight impatiently for what rightly belongs to him or her). The proverb is used to express the African thought of transparent dialogue that can be applied in theological deliberations; leading to sound theological conclusions adequate to address the corruption in the socio-political landscape. Transparency is explained from the African concept of addressing socio-political struggles. Theology calls for robust dialogue for the alternative society. This calls for understanding of African thought of fighting impatiently for the marginalized and the poor-a mandate that is similar to the church's calling for liberating the oppressed masses through dialogue with others and communities in context. A special exploration is made through the symbiosis of dogma and kerygma for the incessant intervention of theology on behalf of the silent masses. An appeal is made for liberation theology and mainstream theology to dialogue in order for communities to experience salvation authentically.
\end{abstract}

Keywords: theology; dialogue; kerygma; transparency; liberation

\section{Introduction}

A socio-cultural approach is applied in this paper to reinforce the importance of theological dialogue as a way of addressing injustice in social structures. The central theme of transparency in dialogue is promoted as a preferred alternative, since it is supported by dogma and kerygma that speaks on behalf of the victims of social injustice. To strengthen this socio-cultural approach a biblical example of Paul's relationship with the Corinthians is cited, together with Romans 10's injunction of homologia and credo. The historical silence of mainstream theology is challenged to synergize with the liberation theology in order to bring a balance between a belief system (dogma) and the confession of faith.

This Setswana proverb serves as a guideline, an appeal, or encouragement during the times of crises when intervention seems far-fetched. It carries a connotation of waiting patiently, of patriotism, standing for what rightly belongs to one, and perseverance during and after a dialogue. It is an African expression of remaining resilient and waiting for positive outcomes. The proverb is used in sociological context of human interactions aiming to find a solution, and in theological dialogue for the same intended solution. The roots and the meaning of the proverb orbits around the justice system in a Setswana culture. The patriot or the arbitrator (who unlike in the normal justice system is not a private mediator, but a participant in legal processes) pleads incessantly for justice to take its course. Theologians are beset with struggles for political reactions, economic crisis, and human dignity degradation perpetuated by the neo-colonialist regimes in the highest echelons of political

1 Setswana is one of the Southern African language groups, mostly spoken in Botswana, South Africa and Namibia. It is estimated that more than seven million people speak it. 
occupations. The silent and suffering masses find themselves in this sphere and try to philosophize in order to interpret their demise and misery. There is the need for theological voice from African understanding of dialogue deliberated in and through transparency.

Moseka phofu ya gaabo ga a tshabe go swa lentswe is used in this paper as a special appeal to theology to speak vigorously, vivaciously, and vividly. The speaking into the situation is precipitated by dogma, which is a theological conviction, "the mysteries of faith" that must be complemented with kerygma, which is "the truth that is openly proclaimed in the church" (Sauter 2003, pp. 24-25). Since this proverb carries the meaning of patriotism, it can be ascribed theologically as promoting Christian apologia. Just as much as patriotism is an attachment to one's homeland, so is theologians' attachment to dogma and kerygma. Just as this attachment is emotional and relates to one's ethnic, cultural, political or socio-historical aspects, so should theologians be attached to common history, faith confessions, and liturgical traditions. Theologians are not called to be the secret agents of God's kingdom, but the heralds who are "to make a dramatic declaration in an atmosphere of importance and wonder" (Resane 2010, p. 87). Their voice should be the proclamation and the declaration of the new order, which is God's kingdom (Resane 2010, p. 86). Their acts of kerygma are expected to be vocal and audible enough in the chaotic world-and this should be incessant. This is a moseka phofu (a herald) who is not afraid to lose voice to defend what rightly belongs to her. In the African worldview, a moseka phofu's voice is loud and clear. His voice warns the community of the ensuing danger. He alerts the society of the authorities' intentions, like the king's coming, new directions to be taken or even calling the assembly. This tells us that in this context, engagement in dialogue should be an incessant theological deliberation undertaken in a transparent procedures and processes. Theology is a rhetoric which is concerned with the power to speak or speaking truth to power. This is done through passion, as ((Smit 2014, p. 33), in Dibeela, Lenka-Bula \& Vellem) in reference to Boesak defines it as theological convictions that undergird passion for political and rhetorical power.

\section{Transparent Theological Dialogue}

\subsection{Transparency in Theological Dialogue-One Biblical Example}

In the recent past, transparency is associated with winning back the disillusioned followers, subordinates, or partners (consumers, stakeholders, students etc.). Historically, in Setswana culture, the voice of moseka phofu was an alarm that broke the silence or disillusionment in the community. In certain instances, it was the voice signaling an ensuing or emerging hope. In politics, transparency is a buzzword used to obtain public office. In general, transparency means clear, unhindered honesty in the way duties are undertaken. One business diary gives a transparency definition that is closer, if not wholly theological, as a

lack of hidden agendas or conditions, accompanied by the availability of full information required for collaboration, cooperation, and collective decision making ... an essential condition for a free and open exchange whereby the rules and reasons behind regularity measures are fair and clear to all participants (Transparency n.d.).

It is, therefore, linguistically correct to conclude that transparency is the full, accurate, and timely disclosure of information. Theologians are the transparent interlocutors of the mind of God in socio-economic structures of society. Moseka phofu (in this case, a theologian) is a transparent communicator of dogma into the human situation to enable humanity to assess and regain the meaning of life. Kusmierz (2016, p. 161) also captures this that:

Theology that takes up the challenge of contributing to the shaping of common life can only be meaningful and relevant if it takes into account its social, political, and economic context.

This theologian is like a believer who exists for others not just for himself. He cannot operate as an island. Moseka phofu is a full member of the community that he is willing to die for, rescue from 
hardships, or alerting them of the new order. His mandate is the patriotic service to the community. This paper promotes the moseka phofu whose endeavor is the recovery of the notion of theological dialogue in contemporary post-liberation South African context. This dialogue calls for accountability to the community where he/she belongs:

Obviously, being part of the faith community the believer is no island and has no exclusive claim to wisdom or to the guidance of the Spirit. He is accountable to his community of faith for ethical decisions (Loubser 2005, p. 327).

Political liberation had come, yet not liberation in totality. West $(2017$, p. 186) resonates this reality that

While political and legal liberation have been secured in South Africa, we have been forced to recognize that we have less liberation than we had imagined.

The new focus of struggle is for socio-economic justice, where theology must be vocal in South Africa. Unfortunately, it occupies the back seat, what Tshaka $(2015$, p. 7) alludes to that

The perception was, we assume, that once political power is gained, the economy would simply conform to the dictates of politics.

In theology, the bottom line transparency is walking together in the light; letting the left hand know what the right hand does. Theologians as the depositories of empirical knowledge of dogma walk together for mutual support to form the united voice, especially in the corrupt socio-political landscape. Theological silence in times of crises is not justified. Ecumenical cooperation becomes effective when transparency is constituent to kerygmatic efforts and attempts in redressing the imbalances in the society. Transparency puts a damper on ecclesiastical fragmentations.

Fragmentary denominational existence put at risk the testimonial and kerygmatic integrity of the one whole Christian church. Different and conflicting brands of Christianity present ironical testimonies and proclamations amidst a spiritually hungry world that has overwhelmingly grown by billions (Delotavo 2012, p. 163).

There are many biblical examples of transparency, but one selected here is to drive the point home. The biblical example of transparency selected is that of Paul's dealing with the Corinthian Church in his second letter to them. In the introductory part of the letter (2 Cor 1:1-24), he addresses the complaint that he had not been open and honest with them. He takes a great delight that his conduct among the Corinthians has always been transparent. He did not display machinations of worldly wisdom, as his abeyance of his visit to them was intended for positive outcomes. The historical interactions with them was permeated by integrity and transparency that would hopefully breed trust (2 Cor 1:12). His continuous and direct involvement with them authenticates his word to them (1:17-20); and this will enhance their understanding, after listening to him. Transparency enhances mutual trust.

In theological dialogue, transparency does not mean freedom of revelation of all information one may possess. There are confidentialities that cannot be divulged, though confidentiality cannot be an excuse to prevaricate, manipulate others, portraying or masquerading in a falsely positive light. When questions surface about motives, a solid record of accomplishment of openness and reliability will be the best antidote for misplaced doubts.

Transparency is so important to Paul's relationship and ministry with the Corinthians that he returns to the theme throughout the letter. We refuse to practice cunning or to falsify God's word; but by the open statement of the truth, we commend ourselves (2 Cor. 4:2). We have spoken frankly to you Corinthians; our heart is wide open to you (2 Cor. 6:11).

\subsection{Theological Dialogue}

Dialogues often take the form of theological consultations, which highlight differences and seek ways of coming closer together through new understandings, reinterpretation or correction of 
misunderstandings, and healing of divisions. The process of discussion itself brings people closer together and helps to break down barriers in social spaces, necessitating the need for social scientists' interventions. Theologians are also the social scientists. Auerbach (2017) of the African Leadership University in the daily Conversation captures this correctly:

Social scientists often assign themselves the role of deconstructor: unpacking power, race, capitalism and consumption with glorious self-righteous abandon. My colleagues and I recognise that we cannot work alone, and require our students to play a central role in contributing to the university's outputs.

Moseka phofu dialogues with the surroundings and people in immediate precincts. To seka, which is the root or verb of moseka, (legal or communal debate) cannot take place on the mountaintop or at the periphery of the community. Tsheko (court case) takes place at the kgotla (court) which is always at the centre of the village. The case is stated and debated with and within the community. Moseka phofu is part of the community. These people are not apart from him/her. Tsheko is a communal dialogue, not like in the normal court of justice where there is the accused and the accuser with the magistrate presiding. In this context, moseka phofu is an advocate, arbitrator or reconciler who patiently plead for what rightly needs action for the plaintiff and the accused. The participants carry different personalities and dialoguing with them may bear some dissenting ideas. It is true that

Dialogue makes participants more sympathetic to one another, even when they disagree, and assists enormously in preparing the ground for negotiation or decision-making on emotion-laden issues (Resane 2017a, p. 204).

In dialogue, consensus is reached. Dialogue brings the warring parties to the table to foster the unified action plan in order to address the situation; or clarify any misunderstanding. In theological dialogue, fragmentations, misunderstandings, and misinformation are all addressed because:

Dialogue is a special kind of discourse that enables people with different perspectives and worldviews to work together to dispel mistrust and create a climate of good faith (Resane 2016, p. 62).

Dialogue kicks theologians out of their parochial silos. When the voice of moseka phofu reverberates, citizens stand attention to listen or to leave or enter a laager for safety. Theological safety is not inside the laager or a silo, but is in jumping out and crossing the dividing walls of self-righteous or self-imposing enclaves such as race, power, economy, traditions, gender, institutions etc. Disagreements in open dialogues are inevitable, but the mutual understanding of the differing opinion or ideology calms down the potential of conflicts and mistrust. Ratzinger (1987, pp. 73-74) referring to Catholic-Anglican dialogues asserts:

Affirmation and criticism are not mutually exclusive: each demands the other. Only when both are joined together do we get an authentic vehicle for true dialogue.

The similar truth is affirmed by Ford (2013, p. 166) that

a theology, which tries to avoid such differences by claiming some unquestionable certainty, or an overview of everyone else, is implausible and unwise.

In dialogue, all voices are heard and respected. It is unacceptable for authentic voices to keep silence during the dialogue. This is especially to African theologians who tend to keep their peace during the dialogues. Their rich insights are muzzled, consequently omitted in crucial policymaking processes. It is a fact that "For us to assess the impact of the voice in its variations, we really need to know what it is" ((Gaie and Tabalaka 2015, p. 379), in Chimhanda, Molobi \& Mothoagae). The silent voice during theological dialogues disservices the think tank.

Moseka phofu is therefore like a person who speaks from the faith position. He enters the public debate and 
translate any claims or concerns deriving from their faiths into a language that is comprehensible—deemable as reasonable — to individuals outside that particular (or outside any) belief system (Fokas 2009, p. 128).

Jesus Christ can be cited as a real moseka phofu, for he walked and lived among the people. He was the Word that lived (tabernacled, tented) among us (John 1:14) as an ordinary man. Indeed, "the cost of ordinariness is involvement in the affairs of people" (Fernando 1995, p. 42). For Jesus, the presence and the proclamation were inseparable. When John the Baptist opted for solitary ministry by moving to the desert, Jesus opted for going to the towns and villages where people were populated. "So, the teaching of Jesus was relevant because He moved among people and knew what was in them" (Fernando 1995, p. 43).

\section{Dogma and Kerygma}

Dogma as well as creeds are the response of believers to the Word of God. Theology is a response to dogma as regula fidei (Rules of faith) and articulus fidei (Articles of faith); and in many ways as veritas (truth). Dogma is a decision to live out (theologise) truth in the social context, because the context is where theology is practiced. That is where liberation theology in its varied aspects, becomes id quod ubique, quod semper, quod ob omnibus creditum est (A valid Christian conviction believed and confessed). Liberation theology plunges into evil social structures; and becomes a genuine mode or expression of the Christian faith.

\subsection{Dogma as Homologia and Credo-Theology in Action}

The manner of speaking of the way dogma is communicated is known as homology, which is the speech of consent. Sauter (2003, p. 28) points out that homology

is language that gives a simple and unrestricted Yes to God's action and therefore must be unconditionally and under all circumstances affirmed.

The Greek homologein, in theological context, means

to declare things that all can hear, to declare what is binding, and at the same time to declare one's own acceptance of what is said, to agree to it, to consent, to confess (Sauter 2003, p. 29).

The key text is Romans 10:9- “If you confess (homologia) with your mouth 'Jesus is Lord', and believe (credo) in your heart that God raised him from the dead, you will be saved". Wethmar alludes to the fact that "The term homologia is indicative not of the content of faith as a deed or an act". Confession is an act rather than just a content. The Christian faith is not merely theoretical talk without any obligation. Faith requires a commitment and a decision. Confession is an enactment of Christian faith, a decision and commitment. Confession (homologia) and belief (credo) are a symbiotic relationship. Credo is a description of the saving work of Christ as content of the Christian faith and as the basis of a commitment to Christ. Commitment and content are inseparable. Commitment to dogma is a confession and belief in incarnation of the love of God by bringing soteriological realities to the context where faith is lived and practiced. Dogma, homologia and credo operate in a balance overflowing out of passion. External practices are the results of intrinsic motivations. This balance is captured by De Gruchy (2011, p. 10) that

Studying theology is a necessary and important academic activity, whereas doing theology is more-it is as a faith-praxis, a committed engagement, a way of being, a passion.

In the same spirit, liberation theology takes biblical text further by expressing the lex esedenti-lex orandi (What I know is what I say) further. In this context,

The biblical text becomes a catalyst in the exploration of pressing contemporary issues relevant to the community; it offers a language so that the voice of the voiceless may be heard ((Modise 2015, p. 4), in Chimhanda, Molobi \& Mothoagae). 
Soteriological experiences are not only spiritual, but also total human liberation. This includes the effects of social justice in the evil society. The incarnation of the love of Christ is the ultimate soteriological experience for humanity. This becomes feasible when dogma is articulated to address human miseries in diverse form. It should always be by bona fides that "dogma aims to articulate the universal implications of the Christian faith" ((Gunton 1998, p. 5), in Pfitzner and Regan). Dogma is not a dead quaere (inquiry), but a viva voce (living voice) in the community "regarding beliefs and practices that are considered essential to the identity or welfare of the group in question" (Lindbeck 1984, p. 74). It is the voice of the people, therefore a vox populi, vox Dei (the voice of the people is the voice of God). That is why it is crucial that the church is perceived, rightly so, as belonging or some form of embodiment. From this embodiment, the voice becomes united and vocal, and in and through the body, theology becomes vocal and practical. Vosloo (2017, p. 224) captures Smit's idea that

Being Christian and being church has to do with "belonging". It also has significant implication for the way one thinks about theology. Theology is done in community.

\subsection{Kerygma as a Liberative Dunamis}

This Greek word, kerygma, is translated proclamation and it refers to various forms of the ministry of the word in mission such as preaching, witnessing, providing literature, theological education etc. It is a joyful invitation to communion with Jesus and His followers. However, it is not a means of scaring people to God with the fear of hell. Proclamation brings the preacher and the audience closer. Some of the famous missiologists in South Africa correctly admonish us that:

We do not proclaim from the distance, from the security of some haven of self-righteousness, but that we come very close to the people we are inviting, in relate to them in solidarity because we are as much in need of the good news as they are (Kritzinger et al. 1994, p. 143).

The British theologian, Macquarrie (1997, p. 10) drives the point home:

Gospel is preaching or proclamation; it is a first order language, which is unselfconscious, a language in which faith speaks in order to awaken faith through the transmission of the good news on which faith has been founded. Christology on the other hand has taken a step back, so to speak, and has become self-conscious and self-critical.

The salvific experiences do not emanate prophetically from the political status quo. The Old Testament narratives are not shaped by the royal stories but by the prophets. "The real actors of history are the prophets. History is written from the perspective of the prophets" (Wittenberg 2012, p. 97). The knowledge of dogma encourages the liberation theologians to be kerygmatic as prophets to confront the imbalances in the society. As moseka phofu, they are not afraid to swa lentswe (lose voice), fighting for the righteousness of faith and civic righteousness. This theology is the involved theology.

We do not have the luxury of the distant view of earth from space, where the airless void refuses to carry the world's cries of despair. We hear the cries all around us and wonder what we are being called to do about it all (Thiemann 1991, p. 98).

Liberation theology as the theology that addresses the current socio-cultural scenes, conscientizes dogmatists to contribute towards "the shaping of industries, nations, institutions, professions, cultures, and practices of all sorts" (Ford 2013, p. 173). It challenges the mainstream theology to stand up from the upper room laurels and move to the public square to become prophetic. The current scenario of corruption in socio-political landscape can be refuted through prophetic theology. Nolan (2012, p. 118) points out that

Prophetic Theology would then mean the outright condemnation of the worship of money in all its forms and a call to action, a call to participate in the struggle against economic injustice. 
This happens when theology advocates a clear option for the poor in the South Africa of today. It is when theology speaks prophetically for the redemption of humanity from the snares of socio-political injustice, oppression, and all forms of marginalization and capture. Koopman (2010, p. 54) reminds us that:

This option for the poor indicates how God works in the world, namely from the particular to the universal. The option for the poor, therefore, also does not imply that even the poor are ends in themselves. In the redemption and liberation of the poor and wronged God is working towards the liberation of all, also of oppressors.

This cannot be achieved in silence. Koopman (2009, pp. 122-23) elsewhere alludes to the fact that prophets are critics. They denounce the realities that are in conflict with the ideals of the new society. It is therefore; accurately conclusive that theology is the vehicle by which the arguments are voiced. Just as a moseka phofu is a vital member of a society, so is theologians as the community members; and as communal people, speak prophetically and in humility. Thiemann (1991, p. 135) highlights this that:

Theologians carry on the conversation, not from a privileged position above tradition, but from within the polyphony of voices that constitute the Christian community.

This brings the liberative dunamis that the voices are within the societal structures where theology is practically appropriated for the benefit of the community in need. Fernando $(1995$, p. 42) also attests this that:

Ministering to people provides the context out of which we preach and teach. Without this we may produce a lot of excellent material, but the material will lack the penetrating insight that is needed to effect change for good in the lives and thinking of people.

\subsection{Rationale for the Return of Liberation Theology}

Theology in South Africa is silent in socio-political landscape. It fails to fight impatiently in matters of morality, human rights abuse, poverty escalation, gender-based abuse, the excessive realpolitik as it contends with vox populi on the grassroots. Theology, though in the social strata of society, is not on the cutting edges of the marginalized poor. It is failing its legitimate mandate as a moseka phofu.

South Africa is at the crossroads as its moral compass is being eroded by unscrupulous people. Since the arrival of freedom and democracy, the voice of the Church is not audible enough to usher and lead people to God. Corruption in the form of oppression of the poor is at an alarming level. The beneficiaries are social elites and political demagogues. Ethics in political governance had become opaque. The populace finds it incomprehensible regarding politics and Church's role in public policies. The opacity in moral values had magnified beyond explanation (Resane 2017b, p. 1).

The emergence of liberation theology over fifty years ago was due to a genuine concern for biblical social justice. It took theology out of silos when almost all major academic theologians were white, middle class and male.

It has attempted to take theology out of the academic ivory tower of the West into the streets ... it has shifted the focus of theological engagement from the intellectual discourse of the Western philosophy to the life and death struggles of poor and oppressed communities ((Modise 2015, p. 3), in Chimhanda, Molobi \& Mothoagae).

Due to its stress on the importance of the wisdom and insight of the poor as the focal point, liberation theology is a moseka phofu to return to the community and conscientise it of its responsibility in the hurting and the marginalized poor. Theologians on the mainstream are invited to opt for openness in dialogue. There should never be a space for neutrality in advocating economic justice. Mind shift is inevitable. This is a theological tug-of-war, but needs to be overcome. It is a struggle that 
demands the taking of sides, leaving no room for neutrality. Resisting neutrality and making ethical decisions draws attention to the importance of prophetic virtue (Le Bruyns 2012, p. 84).

Doing theology includes the critical or prophetic capacity to challenge the politics of abstractions that deny people social justice and economic freedom. The inescapable conclusion is that "God has a concern with the quality of political and economic structures" (Brown 1978, p. 89).

Liberation theology contributes immensely to the interpretation of the Bible and the praxis of the Christian faith. De Gruchy (1991, pp. 131-32) is correct that liberation theology helps contemporary Reformed theologians to return to their inherent liberating dimensions of their dogma and traditions especially the doctrines of grace, justification, sanctification, ecclesiology, the law and the covenant. Liberation theology has a track record of being a starting point of theological relevance; it is a

theology focused on the interpretation of scripture in conjunction with God's intention for mankind, within a given context-an exercise also known as contextualization (Nyiawung 2010, p. 1).

\section{Conclusions}

If theology in South Africa believes in transparent, relevant, and bold dialogue, then it has to come to terms with the fact that liberation theology should be engaged, as it opens "the horizons of those who suffer vicious oppression and domination in their land of birth" (Vellem 2010, p. 3). Conviction espoused in this paper is consonant with Peters $(2000, p$. 347) that "theology can enhance the quality of social life in the world at large by offering a vision of ecumenic wholeness and a proleptic ethic". Theology is legitimized by its prophetic role in social strata of the society. Its voice is a moseka phofu who is not afraid to go swa lentswe for the sake of societal transformation. The body of what we believe and what we confess should incarnately be vocal and visible in the cultural context where humanity is at stake. As pointed out in this paper, a theologian is a moseka phofu who is not a private arbitrator, but a public champion of justice-whose voice echoes through the social structures pleading for justice to take its course. Theologian speaks within the socio-cultural context. Outside this context, dogma and theology in general, "seems barren and lifeless" (McGrath 1997, p. 12). A liberating theology, therefore, should emphasize the humanization that includes working for the humanity of all racial groups in order to gain a status as a deeply pastoral theology. This means that mainstream theology should be both pastoral and prophetic. It should be a passionate theology geared to care giving for the marginalized poor masses in distress. Steyn and Masango (2011, p. 2) stress this:

This pastoral care should find its motivation from within the caregiver's theological convictions, in order to find sufficient energy to sustain the care that is offered.

The mainstream theology must come out of the silos, and cease being parochial. Silence is not the best theology in praxis. Kerygma is dogma verbalized. Theology has to dialogue in public spaces for assertion of its own legitimacy. This can be achieved through dialogue with the liberation theologies of the time. Theological dialogues must be transparent with a goal of achieving maximum results for ecclesiastical and societal transformation. Theology must fight patiently for its convictions that are consonant with Christian dogma and credo. In agreement with Van der Kooi and van den Brink (2017, p. 27):

It is crucial for theology to think from a perspective of the future of the kingdom that God has promised, and to act accordingly. This orientation will result in a critical theology that is at right angles with the status quo of injustice and inequality.

Theological consonance with dogma and credo situates theology in the right place where praxis is most needed. The church in South Africa, and Africa at large, faces the challenges in socio-cultural contexts. Tesfai (1996, p. 95) highlights the reality: 
People are dying of hunger; they are victims of malnutrition, diseases, and economic exploitation. National life is collapsing or on the verge of doing so.

This is the context where the moseka phofu's voice must echo and resonate the sound with patriotic insistence and patience through transparent dialogues. Theology as a moseka phofu must come out into the public space; ascend from parochial throne and presence itself in the grassroots centers, from periphery to the center. For in the postmodern era:

Theologising should be grass roots, communitarian, doxological, provisional, applied and contextual, rather than addressing questions that interest a theological guild (Murray 2004, p. 302).

This truth has been the focus of this paper. Theology should be vocal and unapologetically assert itself at the center stage of world and human affairs. As Naudé (2015, p. 133) remarks: "theology in a new key needs to be complemented by theology with a new voice". Theology must be chiefly concerned with reasoning about relation between God and God's creation (including humans), together with their ethical behaviors (Pietersen 2015, p. 120). Furthermore, theology as a moseka phofu must become patriotic in such a way that its prophetic utterances can be heeded by humanity in all spheres of life. There is no doubt that the bottom line remains:

A recognition of theology as a critical inquiry emerging out of deeply held religious convictions can greatly enrich the cultural, intellectual, and spiritual life of our society (Thiemann 1991, p. 167).

Theological declarations, as epistemological as they may be, should transcend all structural delimitations in order to shape the cosmos eschatologically. The exuberance of the 1980s and the 1990s of prophetic appeals to the then South African government to dismantle apartheid should be revived. As in those days, the appeals should take the form of "strongly worded synodical resolutions and press statements, often issued by churches jointly" ((Kritzinger 2013, p. 108), in Plaatjies-Van Huffel and Vosloo). This contribution cannot be silent or through some docile behavior, for it is appropriate for theologians "to reflect on the proper nature of Christian contributions to deliberation about ethical issues in secular public platforms" (Biggar 2011, p. 48). Theological voice is critical in and as endeavors to restore justice in South Africa. Its voice like a moseka phofu should resonate in the halls of civil and social justice, as well as on the ecclesiastical platforms to address injustices in societal structures. The mainstream theology is invited to collaborate with liberation theologies in order to expedite balanced justice in a currently corrupt South Africa where human dignity and degradation is becoming a norm.

Acknowledgments: This research project is financially sponsored by the Transforming Encounters and Critical Reflection: African Thought, Critical Theory, and Liberation Theology in Dialogue.

Conflicts of Interest: The author declares no conflict of interest.

\section{References}

Auerbach, Jess. 2017. What a new university in Africa is doing to decolonise social sciences. The Conversation, May 13. Biggar, Nigel. 2011. Behaving in Public: How to do Christian Ethics. Grand Rapids: W.M. Eerdmans Publishing Company. Brown, Robert McAfee. 1978. Theology in a New Key: Responding to Liberation Themes. Philadelphia: Westminster Press. De Gruchy, John. 1991. Liberating Reformed Theology: A South African Contribution to an Ecumenical Debate. Grand Rapids: Eerdmans Publishers.

De Gruchy, John. 2011. Transforming Traditions: Doing Theology in South Africa Today. Journal of Theology for Southern Africa 139: 7-17.

Delotavo, Alan J. 2012. Contemporary Evangelicalism and the Restoration of the Prototypal Church. London: FreshIdeasBooks. Fernando, Ajith. 1995. The Supremacy of Christ. Wheaton: Crossway Books.

Fokas, Effie. 2009. Welfare at the Intersection between Theology and Politics: A Global Perspective. Journal of Theology for Southern Africa 133: 126-44. 
Ford, David F. 2013. Theology: A Very Short Introduction. Oxford: Oxford University Press.

Gaie, Joseph. B. R., and Abel Tabalaka. 2015. The Ontology and Intricacy of a Voice: Toward a Philosophy of a Voice. In African Theological Reflections: Critical Voices on Liberation, Leadership, Gender and Eco-Justice. Edited by Chimhanda, Fransica H., Victor M. S. Molobi and Itumeleng Daniel Mothoagae. Unisa: Pretoria.

Gunton, Colin Ewart. 1998. Dogma, the Church and the Task of Theology. In The Task of Theology Today. Edited by Pfitzner, Victor C. and Hilary D. Regan. Grand Rapids: Eerdmans Publishers, pp. 1-54.

Koopman, Nico. 2009. Public Theology as Prophetic Theology: More than Utopianism and Criticism. Journal of Theology for Southern Africa 134: 117-30. [CrossRef]

Koopman, Nico. 2010. Churches and Public Policy Discourses in South Africa. Journal of Theology for Southern Africa 136: 41-56.

Kritzinger, Klippies. 2013. The Struggle for Justice in South Africa (1986-1990): The Participation of the Dutch Reformed Mission Church and the Dutch Reformed Church in Africa. In Reformed Churches in South Africa and the Struggle for Justice: Remembering 1960-1990. Edited by Plaatjies-Van Huffel, Marry-Anne and Robert Vosloo. Stellenbosch: Sun Press, pp. 92-117.

Kritzinger, Johannes J., Piet Meiring, and Willem A. Saayman. 1994. On Being Witnesses. Halfway House: Perskor, Orion Publishers.

Kusmierz, Katrin. 2016. Theology in Transition: Public Theologies in Post-Apartheid South Africa. Zurich: LIT Verlang GmbH \& Co., KG Wien.

Le Bruyns, Clint. 2012. Religion and the Economy? On Public Responsibility through Prophetic Intelligence, Theology and Solidarity. Journal of Theology for Southern Africa 142: 80-97.

Lindbeck, George A. 1984. The Nature of Doctrine: Religion and Theology in a Postliberal Age. Louisville: Westminster, Kentucky: John Knox Press.

Loubser, Gys M. H. 2005. Paul's Ethic of Freedom: No Flash in the Galatian Pan. Neotestamentica: Journal of the New Testament Society of South Africa 39: 313-37.

Macquarrie, John. 1997. Jesus Christ in Modern Thought. London: SCM Press.

McGrath, Alister E. 1997. The Genesis of Doctrine: A Study in the Foundation of Doctrinal Criticism. Grand Rapids: W.M. Eerdmans Publishing Company.

Modise, Leepo J. 2015. Liberation Theology as doing theology in post-apartheid South Africa: Theoretical and practical perspectives. In African Theological Reflections: Critical Voices on Liberation, Leadership, Gender and Eco-Justice. Edited by Chimhanda, Fransica H., Victor M. S. Molobi and Itumeleng Daniel Mothoagae. Pretoria: UNISA, pp. 2-17.

Murray, Stuart. 2004. Post-Christendom: Church and Mission in a Strange New World. Milton Keynes: Paternoster Press. Naudé, Piet. 2015. Pathways in Theology: Ecumenical, African and Reformed. Stellenbosch: SunMedia.

Nolan, Albert. 2012. A Luta Continua: The Struggle and Theology: Yesterday, Today and Tomorrow. Journal of Theology for Southern Africa 143: 116-18.

Nyiawung, Mbengu D. 2010. The prophetic witness of the church as an appropriate mode of public discourse in African societies. HTS Teologiese Studies/Theological Studies 66: 1. [CrossRef]

Peters, Ted. 2000. God-The World's Future: Systematic Theology for a New Era, 2nd ed. Minneapolis: Augsburg Fortress. Pietersen, Herman Johan. 2015. The Four Types of Christian Theology. Johannesburg: Knowledge Resources Publishing. Ratzinger, Joseph. 1987. Church, Ecumenism, and Politics: New Endeavors in Ecclesiology. San Francisco: Ignatius Press. Resane, Thomas. 2010. Proclamational Evangelism must be Balanced with Incarnational Evangelism to Validate Postmodern Evangelism. The South African Baptist Journal of Theology 19: 86-103.

Resane, Thomas. 2016. Africanising a theological discipline: Paradigm shifts for the new trends. In Theology and the (Post) Apartheid Condition: Genealogies and Future Directions. Edited by Venter, Rian. Bloemfontein: Sun Press.

Resane, Thomas. 2017a. Communion Ecclesiology in a Racially Polarised South Africa. Bloemfontein: Sun Media.

Resane, Thomas. 2017b. The Church's prophetic role in the face of corruption in the South African socio-political landscape. Pharos Journal of Theology 98: 1-13. Available online: http//:www.pharosjot.com (accessed on 11 September 2017).

Sauter, Gerhard. 2003. Gateways to Dogmatics: Reasoning Theologically for the Life of the Church. Grand Rapids: W.M. Eerdmans Publishing Company.

Smit, Dirkie. 2014. Resisting 'Lordless Powers': Boesak on Power. In Prophet from the South: Essays in Honour of Allan Aubrey Boesak. Edited by Prince, Dibeela, Puleng Lenka-Bula and Vuyani Vellem. Stellenbosch: Sun Press. 
Steyn, Tobias H., and Maake J. Masango. 2011. The theology and praxis of practical theology in the context of the Faculty of Theology. HTS Teologiese Studies/Theological Studies 67: 2. [CrossRef]

Tesfai, Yacob. 1996. Liberation and Orthodoxy: The Promise and Failures of Interconfessional Dialogue. Maryknoll and New York: Orbis Books.

Thiemann, Ronald F. 1991. Constructing a Public Theology: The Church in a Pluralistic Culture. Louisville: Westminster, Kentucky: John Knox Press.

Transparency. n.d. BusinessDictionary.com. WebFinance, Inc. Available online: http:/ / www.businessdictionary. com/definition/transparency.html (accessed on 20 July 2017).

Tshaka, Rothney S. 2015. The black church as the womb of black liberation theology? Why the Uniting Reformed Church in Southern Africa (URCSA) is not a genuine black church? HTS Teologiese Studies/Theological Studies 71: 3. [CrossRef]

Van der Kooi, Cornelis, and Gijsbert van den Brink. 2017. Christian Dogmatics: An Introduction. Grand Rapids: W.B. Eerdmans Publishing.

Vellem, Vuyani S. 2010. Prophetic Theology in Black Theology, with special reference to the Kairos document. HTS Teologiese Studies/Theological Studies 66: 1. [CrossRef]

Vosloo, Robert. 2017. Reforming Memory: Essays on South African Church and Theological History. Stellenbosch: SunMedia. West, Gerald O. 2017. The Co-optation of the Bible by 'Church Theology' in Post-liberation South Africa: Returning to the Bible as a 'Site of Struggle'. Journal of Theology for Southern Africa 157: 185-98.

Wittenberg, Gunther. 2012. Resistance Theology in the Old Testament: Collected Essays. Pietermaritzburg: Cluster Publications.

(C) 2018 by the author. Licensee MDPI, Basel, Switzerland. This article is an open access article distributed under the terms and conditions of the Creative Commons Attribution (CC BY) license (http://creativecommons.org/licenses/by/4.0/). 